\title{
AN EVALUATION OF CHARACTERISTICS OF ENTREPRENEURS BY STUDENTS OF CZECH AND SLOVAKIAN UNIVERSITIES AND THEIR TENDENCY TOWARDS ENTREPRENEURSHIP \\ Ján Dvorský ${ }^{1}$, Zora Petráková ${ }^{2}$, Martina Jurigová ${ }^{3}$
}

\begin{abstract}
The aim of this article is to compare the assessment of significance of personality characteristics of entrepreneurs in the Czech and Slovak Republic as well as the tendency of students to start entrepreneurships after graduating from university. The research sample consisted of 409 students from 14 universities studying business in the last year in the Czech Republic and 568 students from 8 universities studying in the Slovak Republic. In order to meet the paper's aim, statistical hypotheses were formulated and validated using the Z-score method. One result is that students working in universities in the Slovak Republic are more interested that Czech students in doing business within three years after finishing their studies, unless unexpected circumstances happen in their families. More than $75 \%$ of the addressed students at the Slovak university considered endurance, expertise, responsibility and risk awareness as the most important qualities of an entrepreneur. More than $60 \%$ of Czech students have the same opinion. There are significant differences in opinions of the students from the Czech Republic and the Slovak Republic.
\end{abstract}

JEL Classification Numbers: M13, D83; DOI: http://dx.doi.org/10.12955/cbup.v6.1138

Keywords: Students, characteristics of entrepreneur, entrepreneurship, Czech Republic, Slovak Republic

\section{Introduction}

The main theme during the economic and financial crisis of 2007/2008 was the unemployment of young people with college education (Lenaro et al., 2015; Papadaki et al., 2017). Nearly ten years have passed since the beginning of the 2007/2008 economic and financial crisis. Questions regarding the improvement of the business environment and the growth of the economy will always be up to date despite past or future crises. One of the main indicators of the quality of higher education is the ability of graduates to prove competent in the business environment of their country (Dacin et al., 2010; Jones et al., 2011). Specifically, the economic faculties of Universities are expected to educate and produce future entrepreneurs who will be the driving force of the economy. Young people focusing on economic studies are among the group of people representing the future engine of micro-enterprises, small and medium-sized enterprises thanks to their qualities (acquired by the academic, family and social environment).

In recent times, the topic of whether it is worthwhile to be a businessman is getting more attention. This issue is being dealt with by several authors in their research, namely Franke et al. (2004), Gurol \& Atsan (2006), Lafuente \& Vaillant (2013), Gupta et al. (2014) and other authors. The state, through its ministries, authorities and organizations, should provide conditions that would encourage young people to start doing business in their own country. Social and financial benefits play an important role in deciding whether or not to start a business.

An equally interesting field of research is also the observation of the attitudes of the students in the last years of the university studies of economics towards the claims concerning the personality characteristics of the entrepreneur. In this article, we will address the question of whether university students consider the following qualities of an entrepreneur as the most important ones: responsibility, endurance, expertise and risk awareness. We also study the tendency of students to start a business after finishing university within three years unless unpredictable circumstances arise. After formulating the main goal of the article, the methodology and the methods, we will focus on formulating the results of the comparison of evaluation by the students from the Czech and Slovak universities on the statements of the entrepreneur's personal qualification (characteristics) in the results and discussion sections.

\footnotetext{
${ }^{1}$ Tomas Bata University in Zlín, Faculty of Management and Economics, Department of Enterprise Economics, Zlín, Czech Republic, j1dvorsky@fame.utb.cz

${ }^{2}$ Slovak University of Technology in Bratislava, Faculty of Civil Engineering, Bratislava, Slovak Republic, zora.petrakova@stuba.sk

${ }^{3}$ Slovak University of Technology in Bratislava, Faculty of Civil Engineering, Bratislava, Slovak Republic, martina.jurigova@stuba.sk
} 


\section{Literature review}

Several authors focused their research on the personality characteristics needed for entrepreneurial activities as well as the tendency of university students to start doing business. The following is a brief overview of the case study results.

Di Zhang \& Bruning (2011) claimed that personality characteristics affect the performance of their business. Therefore, they point out that entrepreneurship is not appropriate for everyone. Also, the results show that entrepreneurs who have learned certain qualities do not achieve as good performance in their companies in comparison to the entrepreneurs who claim that they have these characteristics as inherent.

Elmuti et al. (2011) found that based on their results of research in Palestine on a sample of 285 entrepreneurs, they came to the conclusion that one of the main motives for doing business in the country is their inner transformation as well as the ability to achieve success in society with the feeling of ownership of the company.

Zeffane (2014) points to the relationship between individualism and collectivism. These attributes are very important but have to be in equilibrium in the potential individual who wants to become an entrepreneur. It points to the fact that the youth in the Middle East countries are influenced by collectivism in education. But to achieve success in the business environment it is necessary to be an individualist who will focus on the success of the business. On the contrary, in European countries, Zeffane perceives the need for collectivization, because strong individualism and egoism are counterproductive in these countries.

Staniewski et al. (2016) attempted to assess personal predispositions of entrepreneurs in Poland as well as to compare enterprises according to the indicators of economic success in entrepreneurship in small and medium-sized enterprises. The results of the study carried out in 2008 to 2012 on a sample of 294 companies described the core personality predispositions of the entrepreneur, which may have an impact on commitment to a company and the functioning of the company.

Bernat et al. (2017) stated in the conclusions of their publication that they identified a set of factors linked to the decision to become entrepreneurs in Latin America. The authors point out that the key features are: education, risk tolerance, car ownership, job satisfaction and ownership of a company. Features such as age, and the possibility to get a loan are also important factors associated with business activity.

In its case study results, Viinikainen et al. (2017) states that attributes such as aggression, leadership, responsibility, and energy are features that can lead to assert oneself easier in the business environment in adulthood. He also argues that having a leadership feature at an early age is significantly associated with a higher likelihood of becoming an entrepreneur and being successful in doing business.

\section{Aim, methodology, data and methods}

The aim of this article is to compare the evaluation and significance of personality traits of entrepreneurs in the Czech and Slovak Republics as well as the tendency of the students to start entrepreneurship after graduating from university. Respondents of the questionnaire survey are students studying at universities in the Czech and Slovak Republics.

In order to meet the main goal of the article, students' attitudes were investigated using the online questionnaire. The questionnaire was completed by students in the last year of their business studies. The questionnaire consisted of the nine most important factors of tendency toward entrepreneurship: social environment, state support for entrepreneurship, the macroeconomic environment, the quality of the business environment, access to financial resources, the quality of higher education in the country, the characteristics of the entrepreneur, and the benefits and disadvantages of business. For each factor, four statements were formulated from which the students could choose one of the following answers: totally agree, agree, neither agree nor disagree, disagree, totally disagree.

The sample of respondents consisted of 977 students. Of these, 409 students were from 14 universities in the Czech Republic (CR) and 568 students from 8 universities in the Slovak Republic (SR). The representativeness of each student sample was ensured by the diversity of the partner universities addressed: 
From the Czech Republic - the Technical University of Liberec, the University of Applied Business Newton College in Brno, the University of Economics in Prague, he Private University of Business in Prague, Masarykova University in Brno, Academia Sting in Brno, the University of Business and Law in Prague, the Palacky University in Olomouc, the University of Pardubice, the University of Mining Technical University Ostrava, the Technical University in Brno, the Tomas Bata University in Zlin, the Moravian University in Olomouc, and finally the Mendel University in Brno.

From the Slovak Republic - the Economic University in Bratislava, Trenčin University of Alexander Dubček in Trenčín, the Žilina University in Žilina, the Prešov University in Prešov, the University Mateja Bela in Banska Bystrica, the Technical University in Zvollen, the Technical University of Košice, the Pan-European University in Bratislava.

To fulfil the goal of the personal qualities factors of the entrepreneur, the authors of the article have formulated the following statistical hypotheses:

H1: More than $50 \%$ of students agree with the statement that an entrepreneur does not have to have innate characteristics. There are statistically significant differences in positive responses (totally agree, agree) in the Czech Republic and the Slovak Republic.

$\mathrm{H} 2$ : More than $50 \%$ of students agree that qualities such as expertise, endurance, responsibility and risk awareness are the most important for the entrepreneur. There are statistically significant differences in positive responses (I totally agree, agree) in the Czech Republic and the Slovak Republic.

H3: More than $50 \%$ of students agree with the statement that it is easier to start a business, when their relatives already run a business. There are statistically significant differences in positive responses (totally agree, agree) in the Czech Republic and the Slovak Republic.

H4: More than $50 \%$ of students agree with the statement that everyone has business prerequisites. There are statistically significant differences in positive responses (I totally agree, agree) in the Czech Republic and the Slovak Republic.

H5: More than $50 \%$ of students agree with the claim that they will start doing business within three years unless they encounter unforeseen circumstances. There are statistically significant differences in positive responses (totally agree, agree) in the Czech Republic and the Slovak Republic.

We wanted to determine how the personal characteristics of entrepreneurs (innate qualities, expertise, endurance, responsibility and risk awareness influence the tendency for entrepreneurship. We assume that these personality traits are among the most significant. Personal characteristics of entrepreneurs: K11: An entrepreneur does not have to have special innate qualities, K12: The most important personality qualities of the entrepreneur are expertise, endurance, responsibility and risk awareness K13: It is easier to do business if one of the close relatives has already done business, K14: Every person has prerequisites to do business. The student was able to express his/her opinion on his/her tendency to start a business by response to the statement: KX: If I do not experience unforeseen circumstances, I will start my business within three years.

In order to evaluate the given hypotheses essential to meet the main goal of the article, we used the descriptive statistics tools (frequency, sum) in the first step. In order to determine the frequency of the students' answers, we used a simple sorting of the statistical sign (K11, K12, K13, K14, KX) and the sorting according to two statistical features (country - ČR, SR and type of answer). Descriptive characteristics are needed to calculate the Z-score. The Z-score method was applied to confirm or deny our statistical hypotheses $(\mathrm{H} 1, \mathrm{H} 2, \mathrm{H} 3, \mathrm{H} 4$ and $\mathrm{H} 5)$. The level of significance of the testing was determined with a p-value of 0.05 . The conditions for carrying out the Z-test (normal distribution of samples according to statistical features and the representativeness of the sample - number of students) were fulfilled. All these results were analysed using the SPSS Statistics analytical software for data evaluation.

\section{Results}

In the following tables (Table 1, Table 2, Table 3, Table 4 and Table 5), we present the results of the comparison of the assessments of attitudes of students to the personality characteristics of entrepreneur and the tendency of students for entrepreneurship after finishing university. 
Table 1: Comparison of student assessments for the statement that the entrepreneur does not have to have special innate characteristics.

\begin{tabular}{|c|c|c|c|c|}
\hline \multirow[b]{2}{*}{ K11 } & \multicolumn{2}{|c|}{ Location of university } & \multirow[b]{2}{*}{ Z-score } & \multirow[b]{2}{*}{$\mathrm{p}$-value } \\
\hline & $\begin{array}{l}\mathrm{C} \mathrm{R} \\
{[\%]}\end{array}$ & $\begin{array}{l}\text { SR } \\
{[\%]}\end{array}$ & & \\
\hline \multirow{2}{*}{\begin{tabular}{|l|} 
totally agree \\
$7.8 \%$ of students \\
\end{tabular}} & 35 & 41 & \multirow[t]{2}{*}{0.771} & \multirow[t]{2}{*}{0.441} \\
\hline & $8.6 \%$ & $7.2 \%$ & & \\
\hline \multirow{2}{*}{$\begin{array}{l}\text { agree } \\
28.5 \% \text { of students }\end{array}$} & 100 & 178 & \multirow[t]{2}{*}{-2.354} & \multirow[t]{2}{*}{0.018} \\
\hline & $24.4 \%$ & $31.3 \%$ & & \\
\hline \multirow{2}{*}{$\begin{array}{l}\text { (1+2) to the total number ratio } \\
36.2 \% \text { of students }\end{array}$} & 135 & 219 & \multirow[t]{2}{*}{-1.780} & \multirow[t]{2}{*}{0.075} \\
\hline & $33 \%$ & $38.9 \%$ & & \\
\hline \multirow{2}{*}{$\begin{array}{l}\text { neither agree nor disagree } \\
6.9 \% \text { of students }\end{array}$} & 21 & 46 & \multirow[t]{2}{*}{-1.808} & \multirow[t]{2}{*}{0.070} \\
\hline & $5.1 \%$ & $8.1 \%$ & & \\
\hline \multirow{2}{*}{$\begin{array}{l}\text { disagree } \\
47.8 \% \text { of students }\end{array}$} & 204 & 263 & \multirow[t]{2}{*}{1.104} & \multirow[t]{2}{*}{0.271} \\
\hline & $49.9 \%$ & $46.3 \%$ & & \\
\hline \multirow{2}{*}{$\begin{array}{l}\text { totally disagree } \\
9.1 \% \text { of students }\end{array}$} & 49 & 40 & \multirow[t]{2}{*}{2.646} & \multirow[t]{2}{*}{0.008} \\
\hline & $12 \%$ & $7 \%$ & & \\
\hline
\end{tabular}

Notes: ČR - Czech Republic, SR - Slovak Republic. Source: Authors

The results in Table 1 show that 354/977 (36.2\% of students) totally agree or agree with the statement that an entrepreneur does not have to possess any innate properties. There are no statistically significant differences $(Z$-score $=-1.78 ; \mathrm{p}$-value $=0.075)$ between the positive (totally agree, agree) student assessments from in Czech Republic and the Slovak Republic on "K11" statement. Therefore, we reject the $\mathrm{H} 1$ hypothesis due to the level of significance.

Table 2: Comparison of student assessments for the statement, that the most important personal qualities of the entrepreneur are expertise, endurance, responsibility and risk awareness.

\begin{tabular}{|c|c|c|c|c|}
\hline \multirow[b]{2}{*}{ K12 } & \multicolumn{2}{|c|}{ Location of university } & \multirow[b]{2}{*}{ Z-score } & \multirow[b]{2}{*}{ p-value } \\
\hline & $\begin{array}{l}\mathrm{C} \mathrm{R} \\
{[\%]}\end{array}$ & $\begin{array}{l}\text { SR } \\
{[\%]}\end{array}$ & & \\
\hline \multirow{2}{*}{$\begin{array}{l}\text { totally agree } \\
12.7 \% \text { of students }\end{array}$} & 36 & 88 & \multirow{2}{*}{-3.099} & \multirow{2}{*}{0.001} \\
\hline & 8.8 & $15.5 \%$ & & \\
\hline \multirow{2}{*}{$\begin{array}{l}\text { agree } \\
59 \% \text { of students }\end{array}$} & 223 & 353 & \multirow{2}{*}{-2.390} & \multirow{2}{*}{0.017} \\
\hline & $54.5 \%$ & $62.1 \%$ & & \\
\hline \multirow{2}{*}{$\begin{array}{l}(1+2) \text { to the total number } \\
\text { ratio } 71.7 \% \text { of students }\end{array}$} & 259 & 441 & \multirow{2}{*}{-5.132} & \multirow{2}{*}{0.000} \\
\hline & $63.3 \%$ & $77.6 \%$ & & \\
\hline \multirow{2}{*}{$\begin{array}{l}\text { neither agree nor disagree } \\
10.5 \% \text { of students }\end{array}$} & 46 & 57 & \multirow{2}{*}{0.608} & \multirow{2}{*}{0.541} \\
\hline & $11.2 \%$ & $10 \%$ & & \\
\hline \multirow{2}{*}{$\begin{array}{l}\text { disagree } \\
16.4 \% \text { of students }\end{array}$} & 94 & 65 & \multirow{2}{*}{4.820} & \multirow{2}{*}{0.000} \\
\hline & $23.1 \%$ & $11.4 \%$ & & \\
\hline \multirow{2}{*}{$\begin{array}{l}\text { totally disagree } \\
1.5 \% \text { of students }\end{array}$} & 10 & 5 & \multirow{2}{*}{1.962} & \multirow{2}{*}{0.050} \\
\hline & $2.4 \%$ & $1 \%$ & & \\
\hline
\end{tabular}

Notes: ČR - Czech Republic, SR - Slovak Republic. Source: Authors

The results (see Table 2) show that 700/977 (71.7\% of students) totally agree or agree that professional, endurance, responsibility and risk aversion are among the most important personal qualities of an entrepreneur. There are statistically significant differences $(\mathrm{Z}$-score $=-5.132 ; \mathrm{p}$-value $=$ 0.000 ) between the positive (totally agree, agree) student assessments in the Czech Republic and the Slovak Republic for "K12" statement. Therefore, we accept H2 hypothesis.

The results (see Table 3 ) show that $838 / 977$ ( $85.8 \%$ of students) totally agree or agree that it is easier to start doing business if one of their close relatives has already done business. There are no statistically significant differences $(\mathrm{Z}$-score $=-0.707$; $\mathrm{p}$-value $=0.477$ ) among the positive (totally agree, agree) assessments of students in the Czech Republic and the Slovak Republic on "K13" statement. Therefore, the hypothesis $\mathrm{H} 3$ is rejected. 
Table 3: Comparison of student assessments for the statement, that it is easier to do business if one of the close relatives has already done business.

\begin{tabular}{|c|c|c|c|c|}
\hline \multirow[b]{2}{*}{ K13 } & \multicolumn{2}{|c|}{ Location of university } & \multirow[b]{2}{*}{ Z-score } & \multirow[b]{2}{*}{ P-value } \\
\hline & $\begin{array}{l}\text { ČR } \\
{[\%]}\end{array}$ & $\begin{array}{l}\mathrm{SR} \\
{[\%]}\end{array}$ & & \\
\hline \multirow{2}{*}{$\begin{array}{l}\text { totally agree } \\
28.4 \% \text { of students }\end{array}$} & 114 & 163 & \multirow[t]{2}{*}{-0.282} & \multirow[t]{2}{*}{0.779} \\
\hline & $27.9 \%$ & $28.7 \%$ & & \\
\hline \multirow{2}{*}{$\begin{array}{l}\text { agree } \\
57.4 \% \text { of students }\end{array}$} & 233 & 328 & \multirow[t]{2}{*}{-0.242} & \multirow[t]{2}{*}{0.810} \\
\hline & $57 \%$ & $57.7 \%$ & & \\
\hline \multirow{2}{*}{$\begin{array}{l}(1+2) \text { to the total number } \\
\text { ratio } \\
85.8 \% \text { of students }\end{array}$} & 347 & 491 & \multirow[t]{2}{*}{-0.707} & \multirow[t]{2}{*}{0.477} \\
\hline & $84.9 \%$ & $86.4 \%$ & & \\
\hline \multirow{2}{*}{$\begin{array}{l}\text { neither agree nor disagree } \\
6.7 \% \text { of students }\end{array}$} & 24 & 41 & \multirow[t]{2}{*}{-0.835} & \multirow[t]{2}{*}{0.401} \\
\hline & $5.9 \%$ & $7.3 \%$ & & \\
\hline \multirow{2}{*}{$\begin{array}{l}\text { disagree } \\
6.9 \% \text { of students }\end{array}$} & 35 & 33 & \multirow[t]{2}{*}{1.665} & \multirow[t]{2}{*}{0.097} \\
\hline & $8.5 \%$ & $5.8 \%$ & & \\
\hline \multirow{2}{*}{$\begin{array}{l}\text { totally disagree } \\
0.6 \% \text { of students }\end{array}$} & 3 & 3 & \multirow[t]{2}{*}{-* } & \multirow[t]{2}{*}{$-"$} \\
\hline & $0.7 \%$ & $0.5 \%$ & & \\
\hline
\end{tabular}

Note: * Cannot calculate. Source: Authors

Table 4: Comparison of student assessments for the statement, that every person has prerequisites to do business

\begin{tabular}{|c|c|c|c|c|}
\hline \multirow[b]{2}{*}{ K14 } & \multicolumn{2}{|c|}{ Location of university } & \multirow[b]{2}{*}{ Z-score } & \multirow[b]{2}{*}{ p-value } \\
\hline & $\begin{array}{l}\text { ČR } \\
{[\%]}\end{array}$ & $\begin{array}{l}\text { SR } \\
{[\%]}\end{array}$ & & \\
\hline \multirow{2}{*}{$\begin{array}{l}\text { totally agree } \\
5.3 \% \text { of students }\end{array}$} & 14 & 38 & \multirow[t]{2}{*}{-2.244} & \multirow[t]{2}{*}{0.025} \\
\hline & $3.4 \%$ & $6.7 \%$ & & \\
\hline \multirow{2}{*}{$\begin{array}{l}\text { agree } \\
20 \% \text { of students }\end{array}$} & 52 & 143 & \multirow[t]{2}{*}{-4.808} & \multirow[t]{2}{*}{0.000} \\
\hline & $12.7 \%$ & $25.2 \%$ & & \\
\hline \multirow{2}{*}{$\begin{array}{l}(1+2) \text { to the total number ratio } \\
25.3 \% \text { of students }\end{array}$} & 66 & 181 & \multirow[t]{2}{*}{-3.399} & \multirow[t]{2}{*}{0.001} \\
\hline & $16.1 \%$ & $31.9 \%$ & & \\
\hline \multirow{2}{*}{$\begin{array}{l}\text { neither agree nor disagree } \\
9.7 \% \text { of students }\end{array}$} & 27 & 68 & \multirow[t]{2}{*}{-2.795} & \multirow[t]{2}{*}{$\overline{0.005}$} \\
\hline & $6.7 \%$ & $12 \%$ & & \\
\hline \multirow{2}{*}{$\begin{array}{l}\text { disagree } \\
52.4 \% \text { of students }\end{array}$} & 228 & 284 & \multirow[t]{2}{*}{1.774} & \multirow[t]{2}{*}{0.076} \\
\hline & $55.7 \%$ & $50 \%$ & & \\
\hline \multirow{2}{*}{$\begin{array}{l}\text { totally disagree } \\
12.6 \% \text { of students }\end{array}$} & 88 & 35 & \multirow[t]{2}{*}{7.137} & \multirow[t]{2}{*}{0.000} \\
\hline & $21.5 \%$ & $6.1 \%$ & & \\
\hline
\end{tabular}

Notes: ČR - Czech Republic, SR - Slovak Republic. Source: Authors

Table 5: Comparison of student assessments for the statement, that if unforeseen circumstances are not experienced, they will start business within three years

\begin{tabular}{|c|c|c|c|c|}
\hline \multirow[b]{2}{*}{ KX } & \multicolumn{2}{|c|}{ Location of university } & \multirow[b]{2}{*}{ Z-score } & \multirow[b]{2}{*}{ P-value } \\
\hline & $\begin{array}{l}\check{C ̌ R} \\
{[\%]} \\
\end{array}$ & $\begin{array}{l}\text { SR } \\
{[\%]}\end{array}$ & & \\
\hline \multirow{2}{*}{$\begin{array}{l}\text { totally agree } \\
8.1 \% \text { of students }\end{array}$} & 33 & 46 & \multirow[t]{2}{*}{-0.017} & \multirow[t]{2}{*}{0.984} \\
\hline & $8.1 \%$ & $8.1 \%$ & & \\
\hline \multirow{2}{*}{$\begin{array}{l}\text { agree } \\
24 \% \text { of students }\end{array}$} & 77 & 157 & \multirow[t]{2}{*}{-3.185} & \multirow[t]{2}{*}{0.001} \\
\hline & $18.8 \%$ & $27.6 \%$ & & \\
\hline \multirow{2}{*}{$\begin{array}{l}(1+2) \text { to the total number ratio } \\
32.1 \% \text { of students }\end{array}$} & 110 & 203 & \multirow[t]{2}{*}{-2.922} & \multirow[t]{2}{*}{0.003} \\
\hline & $26.9 \%$ & $35.7 \%$ & & \\
\hline \multirow{2}{*}{$\begin{array}{l}\text { neither agree nor disagree } \\
28.2 \% \text { of students }\end{array}$} & 108 & 168 & \multirow[t]{2}{*}{-1.086} & \multirow[t]{2}{*}{0.275} \\
\hline & $26.4 \%$ & $29.6 \%$ & & \\
\hline \multirow{2}{*}{$\begin{array}{l}\text { disagree } \\
30 \% \text { of students }\end{array}$} & 145 & 148 & \multirow[t]{2}{*}{3.162} & \multirow[t]{2}{*}{0.001} \\
\hline & $35.5 \%$ & $26.1 \%$ & & \\
\hline \multirow{2}{*}{$\begin{array}{l}\text { totally disagree } \\
9.7 \% \text { of students }\end{array}$} & 46 & 49 & \multirow[t]{2}{*}{1.363} & \multirow[t]{2}{*}{0.174} \\
\hline & $11.2 \%$ & $8.6 \%$ & & \\
\hline
\end{tabular}

Notes: ČR - Czech Republic, SR - Slovak Republic. Source: Authors 
The results (see Table 4) show that $247 / 977$ (25.3\% of students) totally agree or agree with the statement that every person has business prerequisites. There are statistically significant differences (Z-score $=-3.399 ; \mathrm{p}$-value $=0.001)$ among the positive (totally agree, agree) student assessments in the Czech Republic and the Slovak Republic on the "K14" statement. Therefore, we accept the H4 hypothesis.

The results (see Table 5) show that $247 / 977$ (32.1\% of students) totally agree or agree with the statement that if unforeseen circumstances are not experienced, they will start business within three years. There are statistically significant differences $(Z$-score $=-2.922 ; \mathrm{p}$-value $=0.003$ ) among the positive (totally agree, agree) assessments of students in the Czech Republic and Slovak Republic on the "KX" statement. Therefore, we accept the H5 hypothesis.

\section{Discussion}

The above results of the assessment of the personal characteristics of an entrepreneur by students from universities in the Czech Republic and the Slovak Republic show that more than $75 \%$ of students in higher education institutions in the Slovak Republic consider endurance, competence, risk awareness as the most important characteristics of an entrepreneur. More than $60 \%$ of the students from the Czech Republic have the same opinion. There are significant differences among students from the Czech Republic and the Slovak Republic; more than $80 \%$ of the addressed students are convinced that students whose family relatives do business tend to be entrepreneurial. Similar attitudes prevail among the students both from the Czech Republic and Slovakia. It can also be stated that students from Slovakian universities are more interested in doing business within three years after they finish their studies, than students from the Czech universities, unless unexpected circumstances occur in their families.

The greatest differences in the students' attitudes between countries (the Czech Republic and the Slovak Republic) were found in the assessment of the statement that every person has the prerequisites to do business. Only $16 \%$ of students responded positively in the Czech Republic, while in the Slovak Republic the number of respondents was almost double at $31.9 \%$.

\section{Conclusion}

The aim of this article is to compare the assessment of the significance of the personality characteristics of the entrepreneur in the Czech and Slovak Republic as well as the tendency of the students to start entrepreneurship after graduating from university. Significant determinants of the students' tendency to start a business after graduation are: their social environment, the state business support, entrepreneurial characteristics, and entrepreneurial advantages and disadvantages. Our article was focused on the personality traits of the entrepreneur.

The authors of the article conclude that more than two out of three students consider following what we consider an entrepreneur's most important personal characteristics: expertise, endurance, responsibility and risk awareness. However, there are differences between student assessments in the Czech Republic and the Slovak Republic. On the contrary, the unity in the positive assessment among students is in the statement that students whose family relatives do business have a better perspective to the tendency to do business. In the upcoming publication, we will focus on other important determinants of the tendency of students to start a business, such as the macroeconomic environment, the quality of the business environment, access to financial resources and the possibility of drawing money from European Union funds. Despite the local nature of research in Central European countries, the authors are convinced of the need to bring students' attitudes to the business environment of the country because they play an important role in the further advancement of the economy.

\section{Acknowledgment}

Grant Agencies of the Academic Alliance (GAAA) project "Comparison of the preferences of college students among the Czech Republic and the Slovak Republic in their professional life and the tendency towards entrepreneurship."

\section{References}

Bernat, L. F., Lambardi, G., Palacios, P. (2017). Determinants of the entrepreneurial gender gap in Latin America. Small Business Economics, 48(3), 727-752. 
Dacin, P. A., Dacin, M. T., Matear, M. (2010). Social Entrepreneurship: Why We Don't Need a New Thory and How We Move Forward From Here. Academy of Management Perspectives. 24(3), 37-57.

Di Zhang, D., \& Bruning, E. (2011). Personal characteristics and strategic orientation: Entrepreneurs in Canadian manufacturing companies. International Journal of Entrepreneurial Behaviour and Research, 17 (1), 82-103.

Elmuti, D., Khoury, G., \& Abdul-Rahim, B. (2011). Entrepreneur's personality, education and venture effectiveness: Perceptions of Palestinian entrepreneurs. Journal of Developmental Entrepreneurship, 16(2), 251-268.

Franke, N., Luthje, C. (2004). Entrepreneurial Intentions of Business Students: A Benchmarking Study. International Journal of Innovation and Technology Management, 1 (3), 269-88.

Gupta, V. K., Goktan, A. B., Gunay, G. (2014). Gender differences in evaluation of new business opportunity: A stereotype threat perspective. Journal of Business Venturing, 29 (2), 273-288.

Gurol, Y., Atsan, N. (2006). Entrepreneurial characteristics amongst university students: Some insights for entrepreneurship education and training in Turkey. Education + Training, 48(1), 25-38.

Jones, P., Miller, C., Jones, A., Packham, G., Zbierowski, P. (2011). Attitudes and motivations of Polish students towards entrepreneurial activity. Education + Training, 53(5), 416-432.

Lafuente, E. M., Vaillant, Y. (2013). Age Driven Influence of Role-Models on Entrepreneurship in a Transition Economy. Journal of Small Business and Enterprise Development, 20 (1), 181-203.

Lenaro, A., Vázquez, J. L., Aza, C. L. (2015). Social cognitive determinants of entrepreneurial career choice in university students. International Small Business Journal, 34 (8), 1053-1075.

Papadaki, S., Novak, P., Dvorsky, J. (2017). Attitude of university students to entrepreneurship. Economic Annals-XXI, 166 (7-8), 100-104.

Staniewski, M. W., Janowski, K., \& Awruk, K. (2016). Entrepreneurial personality dispositions and selected indicators of company functioning. Journal of Business Research, 69(5), 1939-1943.

Viinikainen, J., Heineck, G., Böckerman, P., Hintsanen, M., Raitakari, O., \& Pehkonen, J. (2017). Born entrepreneurs? Adolescents' personality characteristics and entrepreneurship in adulthood. Journal of Business Venturing Insights, 8, 9-12.

Zeffane, R. (2014). Does collectivism necessarily negate the spirit of entrepreneurship? International Journal of Entrepreneurial Behaviour and Research, 20(3), 278-296. 